\title{
A Review of Different Analytical Techniques: Bumetanide
}

\section{Palyam Bhanu and Raja Sundararajan*}

GITAM Institute of Pharmacy, GITAM (Deemed to be University), Visakhapatnam, Andhra Pradesh, India

*Corresponding Author: Raja Sundararajan, GITAM Institute of Pharmacy, GITAM (Deemed to be University), Visakhapatnam, Andhra Pradesh, India.
Received: January 18, 2020

Published: January 23, 2020

(C) All rights are reserved by Palyam Bhanu and Raja Sundararajan.

DOI: $10.31080 /$ ASPS.2020.04.0485

\begin{abstract}
Bumetanide is a potent diuretic. It acts by blocking NKCC-1 cation - chloride co-transporter. The purpose of the present review work is to highlight different analytical methods available for Bumetanide estimation in pharmaceutical preparations and biological samples. Analytical methods such as UV, HPLC HPTLC, GC-MS, LC-MS etc were found from the literature.

Keywords: Bumetanide; HPLC; Methanol; Helium
\end{abstract}

\section{Introduction}

Bumetanide [1] $\left(\mathrm{C}_{17} \mathrm{H}_{20} \mathrm{~N}_{2} \mathrm{O}_{5} \mathrm{~S}\right)$ chemically known as 3-butylamino-4-phenoxy-5-sulfamoylbenzoic acid, is an antiepileptic drug. Bumetanide (Figure 1) is synthesized from 4-chlorobenzoic acid (Mo. Wt. $364.417 \mathrm{~g} / \mathrm{mol}$ ). It is used to treat oedema due to heart failure, liver failure, or kidney problems and high blood pressure. Bumetanide acts by blocking NKCC1 cation-chloride co-transporter and in turn reduced chloride concentration in neurons of brain. This leads to more hyperpolarization activity by GABA, useful for treatment of neonatal seizures.

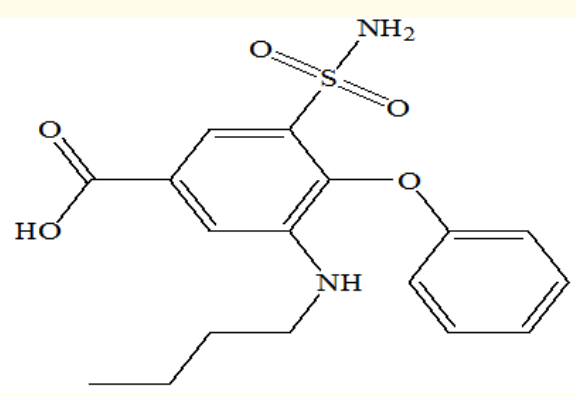

Figure 1: Structure of Bumetanide.
Bumetanide analysed by using different analytical techniques is referenced in this paper. Analytical techniques found in prior-art include spectrophotometry [2,3], spectrofluorimetry [4] (Table 1), HPLC [5-25] (Table 2), LC-MS [26-34] (Table 3), GC-MS [35-38] (Table 4), capillary electrophoresis [39-41] (Table 5), CE-ESI-MS [42], HPTLC [43], Luminescent methods [44] (Table 6).

\begin{tabular}{|l|c|c|c|}
\hline \multicolumn{1}{|c|}{ Reagent } & $\begin{array}{c}\boldsymbol{\lambda} \\
\mathbf{( n m )}\end{array}$ & $\begin{array}{c}\text { Linearity } \\
\boldsymbol{\mu g} / \mathbf{m l}\end{array}$ & Ref \\
\hline $\begin{array}{l}\text { Borate buffer of (pH 9.0) } \\
\text { Phosphate buffer of (pH 7.0) }\end{array}$ & 252 & $5-75$ & {$[2]$} \\
\hline $\begin{array}{l}\text { Phosphate buffer (pH 3.6) } \\
\text { Phosphate buffer (pH 2.0) } \\
\text { Hydrochloric acid }\end{array}$ & 336.21 & $1-60$ & {$[3]$} \\
Distilled water & 345.02 & & \\
\hline Acetonitrile & 345.13 & & \\
\hline
\end{tabular}

Table 1: Review of Spectrophotometric methods. 


\begin{tabular}{|c|c|c|c|c|}
\hline Mobile phase(v/v) & $\lambda(\mathbf{n m})$ & Type of Column & Linearity $(\mu \mathrm{g} / \mathrm{ml})$ & Ref \\
\hline $\begin{array}{l}\text { HPLC } \\
\text { Acetic acid: Acetonitrile: Water (0.1: 80: } 20)\end{array}$ & 220 & $\begin{array}{c}\text { C18 column }(250 \mathrm{~mm} \times 4.60 \mathrm{~mm} \text { i.d, } \\
5 \mu \mathrm{m})\end{array}$ & $0.1-100$ & [5] \\
\hline $\begin{array}{l}\text { HPLC } \\
\text { Methanol: Water }(70: 30)\end{array}$ & 335 & ODS2C18 $250 \mathrm{~mm} \times 4.6 \mathrm{~mm}$ i.d, $5 \mu \mathrm{m}$ & $1-10$ & {$[6]$} \\
\hline $\begin{array}{l}\text { HPLC } \\
\text { Phosphate buffer solution (pH 7.8) - Aceto- } \\
\text { nitrile }(70: 30)\end{array}$ & 216 & $\begin{array}{l}\text { Alitima C8 column }(4.6 \mathrm{~mm} \times 250 \mathrm{~mm} \\
\qquad 5 \mu \mathrm{m})\end{array}$ & $0.6-1.6$ & [7] \\
\hline $\begin{array}{l}\text { HPLC } \\
\text { Methanol-Water-Acetic acid }(60: 40: 0.5)\end{array}$ & 231 & RP-8 (Varian) 250 x $4.6 \mathrm{~mm}, 10 \mu \mathrm{m}$ & $0.04-0.18$ & {$[8]$} \\
\hline $\begin{array}{l}\text { HPLC } \\
\text { Glacial acetic acid: Tetrahydrofuran: Water: } \\
\text { methanol }(2: 5: 45: 50)\end{array}$ & 254 & Bondapak C18 column & -- & [9] \\
\hline $\begin{array}{l}\text { HPLC } \\
0.1 \% \text { 0-pthalaldehyde and Acetonitrile }\end{array}$ & 254 & C18 $250 \mathrm{~mm} \times 4.6 \mathrm{~mm} 5 \mu \mathrm{m}$ & $0.315-1.875$ & {$[10]$} \\
\hline $\begin{array}{l}\text { HPLC } \\
\text { Acetonitrile-Water (50:50) }\end{array}$ & 228 & kromasil C-18 & - & [11] \\
\hline $\begin{array}{l}\text { HPLC } \\
\text { Methanol: Water (75:28) }\end{array}$ & 264 & $\begin{array}{l}\text { Kontron phenomenex column } \\
(4.6 \mathrm{~mm} \times 250 \mathrm{~mm} 5 \mu \mathrm{m})\end{array}$ & $0.038-0.608$ & {$[12]$} \\
\hline $\begin{array}{l}\text { HPLC } \\
0.05 \mathrm{~mol} / \mathrm{L} \text { potassium dihydrogen phosphate } \\
\text {-acetonitrile }(50: 50)\end{array}$ & 267 & - & $20-60$ & [13] \\
\hline $\begin{array}{l}\text { HPLC } \\
\text { Methanol-water }(75: 25)\end{array}$ & 328 & Hypersil ODS2 column & $0.208-1.040$ & [14] \\
\hline $\begin{array}{l}\text { HPLC } \\
\text { Methanol-Water (60: 40) }\end{array}$ & 220 & kromosil ODS $(5 \mu \mathrm{m} \times 4.6,200 \mathrm{~mm})$ & $0.013-0.13$ & [15] \\
\hline $\begin{array}{l}\text { UPLC } \\
\text { Water: Acetonitrile (30: 70) }\end{array}$ & & $\begin{array}{c}\text { Acquity SB C18, } 2 \text { x } 100 \mathrm{~mm}, 1.8 \mu \mathrm{m}, \\
5 \mathrm{~m}\end{array}$ & $12.5-75$ & [16] \\
\hline $\begin{array}{l}\text { HPLC } \\
\text { Acetonitrile-Water (50: 50) }\end{array}$ & -- & $\mu$ Bondapak C18 column & $50-499$ & [17] \\
\hline $\begin{array}{l}\text { HPLC } \\
\text { Acetonitrile -0.01 M Phosphoric acid (35:65) }\end{array}$ & 235 & $\begin{array}{l}\text { C8 reversed phase column (4.8 x } 150 \\
\mathrm{~mm})\end{array}$ & $10-100$ & [18] \\
\hline $\begin{array}{l}\text { HPLC } \\
50 \text { mmol L-1 Phosphate buffer }(\mathrm{pH}=3.0) \text {; } \\
\text { solvent B: Acetonitrile. }\end{array}$ & 214 & $\begin{array}{l}\text { Agilent Zorbax XDB-C18 column } \\
(150 \mathrm{mmlength} \times 4.6 \mathrm{~mm} \\
\text { i.d., } 5 \mathrm{~lm} \text { particle size })\end{array}$ & $5-250$ & [19] \\
\hline $\begin{array}{l}\text { HPLC } \\
0.05 \text { M Phosphate buffer (pH 3) - Acetonitrile }\end{array}$ & 230 & $\begin{array}{l}\text { HP Hypersil ODS ( \&)) 5-flrn column, } \\
200 \mathrm{~mm} \text { x4.6 mm I.D. }\end{array}$ & - & {$[20]$} \\
\hline $\begin{array}{l}\text { HPLC } \\
\text { Eluent A-Water: Triethylamine: Phos- } \\
\text { phoric acid pH-3.3: Acetonitrile } \\
(530 \mathrm{ml}: 145 \mu \mathrm{l}: 650 \mu \mathrm{l}: 470 \mathrm{ml}) \\
\text { Eluent B- } \\
\text { Water: Triethylamine: Phosphoric acid } \\
\text { pH-3.3: Acetonitrile (800ml: } 145 \mu \mathrm{l}: 380 \mu \mathrm{l} \text { : } \\
\text { 200ml) }\end{array}$ & 223 & $\begin{array}{l}\text { Lichrospher } 100 \text { RP-18 OctaDecylSilyl } \\
\text { encapped } \\
(5 \mathrm{~mm}) \text { column }\end{array}$ & - & {$[21]$} \\
\hline $\begin{array}{l}\text { HPLC } \\
\text { Methanol: Water: Glacial acetic acid }(66: 34: 1)\end{array}$ & 228 & Bonded phase C18 column & $5-2000$ & {$[22]$} \\
\hline $\begin{array}{l}\text { HPLC } \\
\text { Methanol: Water: Glacial acetic acid } \\
(70: 30: 0.1)\end{array}$ & 228 & $\begin{array}{c}\text { Reverse phase } \mathrm{C}-18 \text { radial capression } \\
\text { cartridge }\end{array}$ & $\begin{array}{l}\text { Plasma }(2.5-100) \\
\text { Urine }(10-500)\end{array}$ & [23] \\
\hline $\begin{array}{l}60 \%(\mathrm{v} / \mathrm{v}) \text { Methanol in aqueous potassium } \\
\text { dihydrogen orthophosphate }(0.1 \%, \mathrm{w} / \mathrm{v}) \\
\text { Phosphoric Acid }(\mathrm{pH}-4)\end{array}$ & 338 & $\boldsymbol{\mu}$ Bondapak C18 & $1-100$ & {$[24]$} \\
\hline $\begin{array}{l}\text { Methanol: Water: Glacial acetic acid } \\
\text { (65:35:1) }\end{array}$ & 235 & Reverse phase C 18 & - & {$[25]$} \\
\hline
\end{tabular}

Table 2: Review of liquid chromatographic methods. 


\begin{tabular}{|l|c|c|c|}
\hline \multicolumn{1}{|c|}{ Method } & Mobile phase (v/v) & $\begin{array}{c}\text { Linearity } \\
\mathbf{n g} / \mathbf{m l}\end{array}$ & Ref \\
\hline LC-MS & $1 \%$ Acetic acid-Acetonitrile. & $2-200$ & {$[26]$} \\
\hline LC-MS & Acetonitrile-Water (50:50) & $0.3-1$ & {$[27]$} \\
\hline LC-MS & $---3-200$ & {$[28]$} \\
\hline LC-MS & Methanol: Water(50:50) & $1-1250$ & {$[29]$} \\
\hline LC-MS & $\begin{array}{c}1 \% \text { Acetic acid in water- } \\
\text { acetonitrile }\end{array}$ & $1-500$ & {$[30]$} \\
\hline LC-MS & $\begin{array}{c}1 \% \text { Aqueous formic acid : } \\
\text { Acetonitrile (50:50) }\end{array}$ & $1-200$ & {$[31]$} \\
\hline UPLC-MS & $\begin{array}{c}\text { Acetonitrile: } 1 \% \text { Formic acid } \\
\text { (50:50) }\end{array}$ & $2-500$ & {$[32]$} \\
\hline UPLC-MS/MS & $\begin{array}{c}10 \text { mM Ammonium acetate } \\
\text {-Methanol }\end{array}$ & $1.25-12.5$ & {$[33]$} \\
\hline UPLC-MS/MS & $\begin{array}{c}15 m m o l / L \text { Ammonium acetate } \\
\text { solution -Methanol }\end{array}$ & - & {$[34]$} \\
\hline
\end{tabular}

Table 3: Review of liquid chromatographyMass spectrophotometric methods.

\begin{tabular}{|l|c|c|c|c|}
\hline Method & $\begin{array}{c}\text { Carrier } \\
\text { gas }\end{array}$ & $\begin{array}{c}\text { Linearity } \boldsymbol{\mu g} / \\
\mathbf{m l}\end{array}$ & Column & Ref \\
\hline GC-MS & Helium & $2.5-5$ & $\begin{array}{c}\text { Fused-silica cross- } \\
\text { linked methyl silicone } \\
\text { capillary column }\end{array}$ & {$[35]$} \\
\hline GC-MS & Helium & - & HP-1 capillary & {$[36]$} \\
\hline GC-MS & Helium & $\begin{array}{c}\text { Horse urine } \\
0.5-5\end{array}$ & $\begin{array}{c}\text { Capillary Column } \\
\text { VF-DA }\end{array}$ & {$[37]$} \\
\hline GC-MS & Helium & $\begin{array}{c}\text { Human urine } \\
2.5-20\end{array}$ & $\begin{array}{c}\text { Combipal and Factor } \\
\text { Four Capillary Col- } \\
\text { umn VF-DA }\end{array}$ & {$[38]$} \\
\hline
\end{tabular}

Table 4: Review of GC-MS methods.

\begin{tabular}{|l|c|c|c|}
\hline Mobile phase & $\begin{array}{c}\text { Linearity } \\
\boldsymbol{\mu g} / \mathbf{m l}\end{array}$ & $\begin{array}{c}\boldsymbol{\lambda} \\
\mathbf{( n m )}\end{array}$ & Ref \\
\hline $\begin{array}{l}\mathrm{CE} \\
5 \text { mM of triethylamine, } 0.1 \mathrm{lM} \text { of } \\
\text { fluorescein, and 5\% of n-butanol }\end{array}$ & $2.5-125$ & 473 & {$[39]$} \\
\hline $\begin{array}{l}\mathrm{CE} \\
\mathrm{H}_{3} \mathrm{BO}_{3}-\mathrm{Na}_{2} \mathrm{~B}_{4} \mathrm{O}_{7}(\mathrm{pH} 8.98)\end{array}$ & $1-50$ & -- & {$[40]$} \\
\hline $\begin{array}{l}\mathrm{CE} \\
\text { Citrate buffer (pH-5) } \\
\text { Phosphate buffer(pH-7) } \\
\text { Borate buffer(pH 7-10) }\end{array}$ & -- & 350 & {$[41]$} \\
\hline $\begin{array}{l}\text { CE-ESI-MS } \\
40 \text { mM Ammonium formate buffer } \\
\text { (pH 9.40) }\end{array}$ & $0.9-165$ & 214 & {$[42]$} \\
\hline
\end{tabular}

Table 5: Review of Capillary electrophoresis (CE) methods.

\begin{tabular}{|l|c|c|c|c|}
\hline \multicolumn{1}{|c|}{ Method } & Mobile phase & $\begin{array}{c}\text { Linearity } \\
\boldsymbol{\mu g} / \mathbf{m l}\end{array}$ & $\begin{array}{c}\boldsymbol{\lambda} \\
\mathbf{( n m )}\end{array}$ & Ref \\
\hline HPTLC & $\begin{array}{c}\text { Toluene: Ethyl acetate: } \\
\text { Formic acid } \\
\text { (7:3.5:0.5 v/v/v) }\end{array}$ & $100-800$ & 335 & {$[43]$} \\
\hline Luminescent & Methanol & $50-5000$ & 325 & {$[44]$} \\
\hline
\end{tabular}

Table 6: Review of other methods.

\section{Conclusion}

Different analytical methods such as UV, HPLC, UPLC, Capillary electrophoresis and hyphenated techniques such as LC-MS, GC-MS, and CE-ESI-MS were reported in previous research for estimation of Bumetanide. Determination of Bumetanide in biological samples, bulk and pharmaceutical dosage forms were also reported. This review article will be very useful for the researchers to compare any new analytical method developed with that of the previously available methods for the estimation of Bumetanide.

\section{Bibliography}

1. Flamenbaum W., et al. "Pharmacology, therapeutic efficacy, and adverse effects of Bumetanide, a new loop diuretic". Pharmacotherapy 2 (1982): 213-222.

2. Chaitanya B and Raja S. "Method development and validation of Bumetanide by UV spectrophotometric method in bulk and pharmaceutical dosage form". European Journal of Biomedical and Pharmaceutical Sciences 5.3 (2018): 443-450.

3. Annapurna MM., et al. "New spectrophotometric methods for the quantification of Bumetanide tablets". Acta Scientific Pharmaceutical Sciences 3.8 (2019): 91-95.

4. Abd-Elzaher MM., et al. "Characterization of Eu (III) complex for determination of Bumetanide in pharmaceutical preparations and in biological fluids". Egypt Journal of Chemistry 59.5 (2016): 701-718.

5. Annapurna MM., et al. "New Stability Indicating RP-UFLC Method for the Determination of Bumetanide - A Potent Diuretic". Acta Scientific Pharmaceutical Sciences 3.8 (2019): 8490.

6. Rao JR., et al. "Stability indicating RP-HPLC method for Bumetanide in bulk drug and tablet formulation". Asian Journal of Research in Chemistry 2.3 (2009): 266-269.

7. Huang Q., et al. "HPLC Determination of the dissolution of Bumetanide tablets". Chinese Journal of Pharmaceutical Analysis 27.8 (2007): 1285-1287. 
8. Zivanov SD., et al. "High-performance liquid chromatographic method for the determination of Bumetanide in pharmaceutical preparations". Journal of Pharmaceutical and Biomedical Analysis 7.2 (1989): 1889-1892.

9. Seethi R., et al. "Development and validation of RP-HPLC for estimation of Bumetanide in tablet formulation". Indian Journal of Field Veterinarians 9.4 (2014): 46-53.

10. Suresh KP., et al. "RP-HPLC estimation of Bumetanide and its impurities oral solid dosage form". Asian Journal of Chemistry 31.10 (2019): 2215-2221.

11. Kun T. "Content determination of principal agents in Bumetanide tablets by HPLC-Flourimetry". China Pharmacy 19 (2005): 1493-1494.

12. Guo-qin W., et al. "Determination of dissolution of Bumetanide tablets by HPLC". Strait Pharmaceutical Journal 9 (2007): 3436.

13. Bu-juan Y. "Determination of Bumetanide in Bumetanide tablets by HPLC”. China Medical herald 26 (2008): 31-32.

14. Bao-qiang R. "Determination of Bumetanide tablets by HPLC". Strait Pharmaceutical Journal 1 (2006): 77-78.

15. Dong-ming P., et al. "Determination of Bumetanide for injection by HPLC". Chinese Journal of Modern Applied Pharmacy 5 (2006): 404-406.

16. Chaitanya B and Raja S. "Method development, validation and stability studies for determination of Bumetanide in bulk and pharmaceutical dosage form by RP-UPLC". International Journal of Pharmacy and Pharmaceutical Sciences 10.3 (2018): 3542.

17. Legorburu M J., et al. "Quantitative Determination of the Loop Diuretic Bumetanide in Urine and Pharmaceuticals by HighPerformance Liquid Chromatography with Amperometric Detection". Journal of Chromatographic Science 39 (2001): 425430.

18. Ashok KS., et al. "Simultaneous analysis of furosemide and Bumetanide in horse plasma in high performance liquid chromatography". Biomedical chromatography 3.6 (1989): 262-265.

19. Zhuomin Z., et al. "Determination of diuretics in human urine by hollow fibre-based liquid-liquid microextraction coupled to high performance liquid chromatography". Analyst 9 (2008): 1187-1194
20. Cooper SF., et al. "Comprehensive screening procedure for diuretics in urine by high performance liquid chromatography". Journal of Chromatography B, Biomedical Sciences and Applications 489.1 (1989): 65-88.

21. Guchelaar HJ., et al. "A High Performance liquid chromatographic method for the screening of 21 diuretic in human urine". Fresenius Journal of Analytical Chemistry 363.7 (1999): 700-705.

22. Wells TG., et al. "Measurement of Bumetanide in plasma and urine by high performance liquid chromatography and application to Bumetanide disposition". Journal of Chromatography B 570.1 (1991): 235-242.

23. Ameer B and Burlingame MB. "Determination of Bumetanide in human plasma and urine by high performance liquid chromatography with fluorescence detection". Analytical letters 21.9 (1988): 1589-1601.

24. Walmsley LM., et al. "Determination of Bumetanide in the plasma of non-human primates by high performance liquid chromatography". Journal of Chromatography B: Biomedical Sciences and Applications 226.2 (1981): 441-449.

25. Hae-Young P., et al. "Determination of Bumetanide in human plasma by a validated HPLC method and its application to its single dose pharmacokinetics". Journal of Pharmaceutical Investigation 35.1 (2005): 51-55.

26. Deventer K., et al. "Screening for 18 diuretics and probenecid in doping analysis by liquid chromatography-tandem mass spectrometry". Biomedical Chromatography 16 (2002): 529535.

27. Sanz NV., et al. "Determination and characterization of diuretics in human urine by liquid chromatography coupled to pneumatically assisted electrospray ionization mass spectrometry". Journal of Mass Spectrometry 36.6 (2001): 1-18.

28. Patel DS., et al. "Application of a rapid and sensitive liquid chromatography - tandem mass spectrometry method for determination of Bumetanide in human plasma for bioequivalence study". Journal of Pharmaceutical and Biomedical Analysis 66 (2012): 365-370.

29. Yijun LI., et al. "Sensitive isotope dilution liquid chromatography/tandem mass spectrometry method for quantitative analysis for Bumetanide in serum and brain tissue". Journal of Chromatography B Analytical Technologies in Biomedical Life Science 879 (2011): 998-1002. 
30. Deventer K., et al. "Simultaneous determination of betablocking agents and diuretics in doping analysis by liquid chromatography/mass spectrometry with scan-to-scan polarity switching". Rapid Communication in Mass Spectrometry 19 (2005): 90-98.

31. Shobha A., et al. "Comprehensive screening of diuretics in human urine using liquid chromatography tandem mass spectrometry". Analytical Chemistry an Indian Journal 13.7 (2013):270-283.

32. Sachin D., et al. "An ultra-fast and sensitive detection of 165 drugs of abuse in human urine using polarity switching ultraperformance liquid chromatography tandem mass spectrometry". Analytical Chemistry an Indian Journal 15.8 (2015): 319338.

33. John OT., et al. "A high-throughput multicomponent screening method for diuretics, masking agents, central nervous system (CNS) stimulants and opiates in human urine by UPLC-MS/ MS". Journal of Mass Spectrometry 43 (2008): 980-992.

34. Gong XU., et al. "Determination of 37 illegally added in weight losing, lipid lowering and laxative health foods by UPLC-MS/ MS". Chinese Journal of Pharmaceutical Analysis 36.5 (2016): 918-928.

35. Lisi AM., et al. "Screening of diuretics in human urine by gas chromatography-mass spectrometry with derivatisation by direct extractive alkylation". Journal of chromatography B: Biomedical Sciences and Applications 563.2 (1991): 257-270.

36. Beyer J., et al. "Screening procedure for detection of diuretics and uricosurics and/or their metabolites in human urine using gas chromatography-mass spectrometry after extractive methylation". Therapeutic Drug Monitoring 27.4 (2005): 509520.

37. Heinz WH and Rudiger S. "Detection of diuretics in horse urine by GC/MS”. Journal of Analytical Toxicology 16.3 (1992): 194198.

38. Olga Z., et al. "Determination of 8 Diuretics and Probenecid in Human Urine by Gas Chromatography-Mass Spectrometry: Confirmation Procedure". American Journal of Analytical Chemistry 3.4 (2012): 320-327.

39. Xiuhan Y., et al. "Indirect laser-induced fluorescence detection of diuretics separated by capillary electrophoresis". Journal of Separation Science 29 (2006): 677-683.
40. Xinyu Z., et al. "A online-field amplification sample stacking method for the determination of diuretics in the urine by capillary electrophoresis - amperometric detection". Talanta 76.1(2008): 15-20.

41. Gonzalez E., et al. "Direct determination of diuretics drugs in urine by capillary zone electrophoresis using fluorescence detection". Journal of Chromatography B: Biomedical Science Applications 687.1 (1996): 145-150.

42. Minghua L., et al. "A new method for screening and determination of diuretics by on-line CE-ESI-MS". Electrophoresis 28 (2007): 1461-1471.

43. Kumar M., et al. "Development and validation of stability indicating HPTLC method for analysis of Bumetanide in bulk drug and tablet dosage form". Research Journal of Pharmacy and Technology 3.1 (2010): 239-243.

44. Luna T and Olga Z. "Simple and rapid determination of diuretics by luminescent method". Journal of Pharmacy and Pharmacology 4 (2013): 520-527.

\section{Assets from publication with us}

- Prompt Acknowledgement after receiving the article

- Thorough Double blinded peer review

- Rapid Publication

- Issue of Publication Certificate

- High visibility of your Published work

Website: https://www.actascientific.com/

Submit Article: https://www.actascientific.com/submission.php Email us: editor@actascientific.com

Contact us: +919182824667 